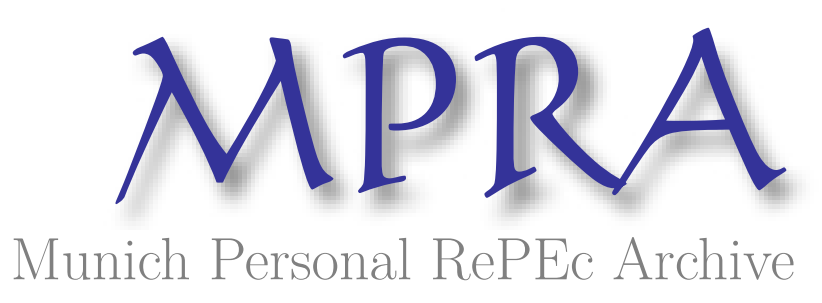

\title{
Information Asymmetry and the Market Response to Open Market Share Repurchases
}

Lee, Bong Soo and Mauck, Nathan

1 March 2014

Online at https://mpra.ub.uni-muenchen.de/54066/

MPRA Paper No. 54066, posted 03 Mar 2014 01:32 UTC 


\title{
Information Asymmetry and the Market Response to Open Market Share Repurchases
}

\author{
Bong Soo Lee \\ Florida State University \\ blee2@cob.fsu.edu \\ (850) 644-4713 \\ Nathan Mauck \\ University of Missouri - Kansas City \\ mauckna@umkc.edu \\ (816) 235-6113
}

\begin{abstract}
This paper proposes a new measure of firm information asymmetry. The information asymmetry measure is based on causality tests relating repurchase information to firm returns. Our results indicate that firms with greater information asymmetry show larger abnormal returns surrounding the announcement of an open market share repurchase. This new information asymmetry proxy remains a significant explanatory factor for announcement abnormal returns after controlling for other conventional information asymmetry proxies, such as firm size, number of analysts following, and analyst forecast dispersion. Further, our measure of information asymmetry is positively related to long-term abnormal returns at one, two, and three-year windows.
\end{abstract}

JEL classification: D82; G35

Key words: Payout policy; Open market share repurchases; Information asymmetry; Time series; Causality 


\section{Introduction}

While the market response to open market repurchase announcements is on average positive, the market responds strongly to some announcements and not strongly to others. ${ }^{1} \mathrm{We}$ examine if the degree of firm information asymmetry helps to explain the market reaction to open market share repurchase announcements. Our measure of information asymmetry is unique in this context and is derived from time series regressions based on Granger (1969) and Sims (1972). While other information asymmetry proxies in the literature capture some aspects of information asymmetry, ours is tailored specifically to the repurchase decision. Specifically, our information asymmetry proxy is based on dynamic causal relations between stock price performance of firms and the announcement of share repurchases during the period 1990-2012. Our information asymmetry proxy helps to explain announcement returns even after controlling for other conventional information asymmetry proxies, such as firm size, number of analysts following, and the dispersion of analyst forecasts.

Market reactions to share repurchases may be related to the perceived motivation and information of the repurchase. The literature provides evidence of the signaling hypothesis (Louis and White, 2007). According to the signaling hypothesis, the motivation for a stock repurchase is to signal undervaluation of a firm to investors. Dittmar (2000) argues that information asymmetry between managers and shareholders can induce firm undervaluation in the market, and that a stock repurchase is the process of releasing information that is available only to managers to the market. Therefore, the information signaled is usually assumed to be firm undervaluation although other motivations for repurchases exist (i.e., stock-based compensation plans, reducing excess cash,

\footnotetext{
${ }^{1}$ Comment and Jarrell (1991), Chan et al. (2004), and Grullon and Michaely (2004), among others, document positive abnormal returns following the announcement of repurchases.
} 
etc.). ${ }^{2}$ The survey of managers by Brav et al. (2005) indicates that undervaluation is the primary reason for repurchasing. However, the literature has not reached a consensus on whether or not managers are able to time repurchases correctly to take advantage of periods of mispricing. Ikenberry et al. (1995), Brockman and Chung (2001), Cook et al. (2004), and Peyer and Vermaelen (2009) conclude that managers are able to time the market while Dittmar and Field (2013) find that frequent repurchasers, who account for the majority of repurchases, are unable and likely not attempting to time the market. Similarly, Jagannathan and Stephens (2003) show that infrequent repurchases show a stronger stock price reaction at announcement. Yook (2010) finds that repurchase announcement abnormal returns are positively related to firm undervaluation and that frequent repurchasing firms do not show positive long-term abnormal returns. Similarly, Babenko et al. (2012) demonstrate that not all repurchases are credible signals of undervaluation. Further, Dittmar and Field (2013) find that the market is not able to determine which repurchases signal undervaluation at the time of the announcement.

Regardless of whether or not the average repurchase indicates timing, it seems clear that some repurchases are informed and others are uninformed. Thus, establishing which firms have relatively higher levels of information asymmetry in the repurchase decision allows us to identify which repurchases send credible signals and which do not. Others have examined conventional

\footnotetext{
${ }^{2}$ The literature shows several reasons for corporate managers to distribute cash through share repurchases. For example, share repurchases provide corporate managers with flexibility in terms of timing and the amount of cash payouts (e.g., Grullon and Michaely, 2002), so many researchers hypothesize that firms use share repurchases to pay out temporary cash flows (Guay and Harford, 2000; Jagannathan et al. 2000; Dittmar, 2000; Lee and Rui, 2007). Some authors hypothesize that firms use share repurchases to distribute excess capital. This excess capital hypothesis relates to the free cash flow hypothesis of Jensen (1986) in that excess capital gives rise to agency costs of overinvestments unless it is distributed to shareholders (e.g., Dittmar, 2000). Some studies provide evidence that the presence of stock option programs influences firms' decisions about share repurchases (Jolls, 1998; Fenn and Liang, 2001; Kahle, 2002; Jun, Jung and Walkling, 2009); that firms use share repurchases to defend themselves against takeovers (Denis, 1990; Billett and Xue, 2007). Tax motives may also influence decisions to repurchase shares because, as compared to dividends, share repurchases provide shareholders with tax benefits (Barclay and Smith, 1988).
} 
and general information asymmetry proxies such as firm size in examining the market response to share repurchases (Chan et al., 2004). However, we propose a repurchase specific information asymmetry proxy in order to better understand the market reaction to share repurchase announcements.

The intuition of our information asymmetry measure is straightforward. If a given repurchase announcement contains predictive information about future stock returns, then it follows that the repurchase is likely based on information possessed by the manager and not the market. In short, firms with higher information asymmetry are more likely to show stronger stock market returns following the open market repurchase. Thus, our measure of information asymmetry is based on time series causality regressions for each repurchasing firm in the sample. Each repurchase announcement is categorized as either an informed or uninformed repurchase. If lagged repurchase information predicts future (six month) returns, with a statistically significant causal relation, that repurchase is labeled as informed. Our interpretation of this is that these informed repurchases are for firms where the level of information asymmetry is sufficiently high as to render the information of the announcement economically meaningful.

Our results indicate that the majority of repurchases are not informed. Regardless of the repurchase measure used, we find that approximately $7 \%$ of all repurchase announcements are informed. Our use of the term "informed" in this case is to describe those firms for which the lagged repurchase variable predicts six month future returns in causality regressions. This is consistent with Dittmar and Field (2013) who find that most repurchases are by frequent repurchasers and that such transactions are not at relatively low prices. 
Informed repurchases result in higher announcement returns than non-informed repurchases, which indicates that the market generally identifies firms with greater information asymmetry at the time of the repurchase announcement. The difference between informed and uninformed abnormal returns is increased for small firms, but the difference is non-existent (i.e., insignificant) for large firms. Thus, smaller firms that are likely to have higher levels of information asymmetry may be further bifurcated based on our more precise measure of information asymmetry. Specifically, the size of the firm does not fully explain firm level information asymmetry in the context of repurchases and our time series based measure offers an alternative measure specific to this purpose. Our results hold when controlling for the size of the repurchase, the frequency of repurchases for a firm, and other traditional proxies for information asymmetry including firm size, analysts following, and the dispersion of analyst forecasts. Finally, we find that firms that we identify as informed outperform the market and other repurchasers in terms of long-term abnormal returns in the one, two, and three year windows.

Our paper is organized as follows. In Section 2, we consider the motivation for using the dynamic causal relation between returns and stock repurchases as the proxy for information asymmetry in stock repurchases. In Section 3, we describe the data and methodology. In Section 4, we present the empirical evidence. In Section 5, we conclude.

\section{Information Asymmetry and Repurchases}

The literature evaluating the ability of managers to time repurchases assumes firm information asymmetry that requires the manager to signal full information to the market. The market, which is aware of the information asymmetry, responds positively to the announcement of share repurchases. The explicit link between information asymmetry and the market response 
to share repurchases has received less attention. Chan et al. (2004) find that small firms are associated with larger announcement abnormal returns relative to large firms upon the announcement of a repurchase program. However, they focus on firm size as a proxy for likely misvaluation as opposed to information asymmetry. As the literature has used firm size (Vermaelen, 1981; Corwin, 2003; Zhang, 2006) as a proxy for information asymmetry, it may be inferred that firms with greater information asymmetry show a relatively larger announcement return. However, firm size is not a direct measure of whether or not the repurchasing firm truly possessed information not contained in the price at the time of the repurchase.

Similarly, the literature has used the dispersion of analyst forecasts (Babenko et al., 2012; Krishnaswami and Subramaniam, 1999; Diether et al., 2002) and the number of analysts following the firm (Chang et al., 2000; Hong et al., 2000; Bushman et al., 2004; Zhang, 2006; Babenko et al., 2012) as proxies for information asymmetry. These measures are also not a direct measure of whether or not a given repurchase contains information not possessed by the market. The preferred way to identify truly informed repurchases is by examining the return performance of repurchasing firms - which is the focus of this paper.

There can be some concerns about using stock returns following repurchases to establish information asymmetry or to identify which repurchases are truly informed. For instance, it is possible that the positive performance used to establish information asymmetry is due to factors not signaled by the repurchase, in which case using the performance would yield a potentially biased identification of an informed repurchase. Similarly, it is plausible that a firm correctly signals undervaluation via a repurchase announcement, but the market does not correct the price in time for our measure to capture the correction. In short, our measure may commit both Type I 
and Type II errors in establishing informed repurchases. However, given that our information asymmetry proxy is based on a statistical test from causality regressions, the results are unlikely to be systematically biased. In order to alleviate this concern, we relate our information asymmetry measure to long-term abnormal returns, in addition to short-term abnormal returns, which capture post announcement performance and control for systemic factors which may drive returns.

There may be other problems with our approach. It may be argued that if markets are efficient, then announcement abnormal returns should correctly signal which repurchases are informed. However, the literature has established a post-repurchase announcement drift that would suggest that using the announcement abnormal returns may be a poor proxy for information asymmetry (Ikenberry et al., 1995; Grullon and Michaely, 2004; Chan et al. 2004). Chan et al. (2004) note that "the evidence, however, indicates that the initial market reaction is not a good predictor of long-term abnormal performance." This statement is related to their results which suggest that the initial market reaction is not only incomplete, but actually unrelated to subsequent return performance. Overall, the literature suggests that the market does not, on average, price the information of repurchase announcements immediately at the time of the announcement.

\section{Data and Methodology}

Data on open market share repurchases is from SDC Platinum. We collect data on all announced share repurchases from 1980-2012. For each repurchase, we identify the date of the announcement and the size of the announced repurchase. Following Grullon and Michaely (2004) and Babenko et al. (2012), we do not exclude financial firms from our sample. We construct two measures of repurchases. The first is a simple indicator which is equal to one if there is a repurchase announced in a given month and is zero otherwise. The second, which is consistent with Babenko 
et al. (2012), is the dollar value of the repurchase divided by the market value of the firm. Using the dollar value of the repurchase rather than the number of shares is due to data availability in SDC Platinum. Specifically, the dollar value of the repurchase is nearly always reported (roughly $90 \%$ reporting) while the number of shares sought is rarely reported (less than $25 \%$ reporting).

We then link the sample of repurchasing firms to CRSP in order to obtain firm stock return and market capitalization data. We obtain return data over the period from 1980-2012. Event study cumulative abnormal returns (CARs) are calculated following Babenko et al. (2012). Specifically, we use a market model approach with an estimation window of (-252 to -44) and a three-day event window of $(-1$ to +1$)$ to construct CAR. CAR is the difference between the observed return and predicted return based on the market model.

Our repurchase sample is linked to Fama and French (1993) factors for our long-term abnormal return calculation. Post-repurchase announcement long-term abnormal returns are calculated following Peyer and Vermaelen (2009) by using the Fama-French (1993) three-factor model. We form equally-weighted calendar time portfolios for firms repurchasing in the past 12 , 24 , or 36 months depending on the horizon of interest. We then run the following regression for the time series of portfolio returns:

$$
\left(R_{i, t}-R_{f, t}\right)=\alpha_{j}+b_{j}\left(R_{m, t}-R_{f, t}\right)+c_{j} S M B_{t}+d_{j} H M L_{t}+\varepsilon_{i, t},
$$

where $R_{i, t}$ is the monthly return of firm $i$ in calendar month $t . R_{f, t}$ and $R_{m, t}$ are the risk-free rate (one-month T-Bill) and the return on the market (equally weighted CRSP return index) for calendar month $t$, respectively. $S M B_{t}$ and $H M L_{t}$ are the return on the size and book-to-market 
factors in calendar month $t$, respectively. Portfolios are formed for the full sample as well as numerous bifurcations based on information asymmetry proxies.

In Table 1 we report summary statistics for the size of the repurchase (repurchase dollar value divided by firm market value), the value of the repurchase (in millions of dollars), the announcement CAR, the number of analysts following the firm close to the time of the repurchase announcement, and the dispersion of analyst forecasts close to the time of the announcement. We document that the average repurchase announcement is for $8.59 \%$ of total firm market value, has a value of $\$ 168.38$ million and an announcement CAR of $2.77 \%$. We note that we are able to calculate announcement abnormal returns for 8,859 repurchase announcements over the 19902012 period. We compare this to other studies and find that our sample is consistent with prior work. For instance, Babenko et al. (2012) find 5,827 announcements over the period 1993-2008. Over this same period, we find a very similar number of deals $(6,128)$ despite the fact that we do not explicitly follow their filtering criteria. Differences between sample size in Babenko et al. (2012) and our paper are due to our paper including more years, both before and after the period examined in Babenko et al.

We find mean and median event (event days -1 to +1 ) cumulative abnormal returns in Table 1 of $2.77 \%$ and $1.78 \%$, respectively, which are both statistically significant at the $1 \%$ level. The announcement CAR in Table 1 is consistent with Grullon and Michaely (2004) who find mean and median CAR over the same three day window $(-1$ to +1$)$ of $2.71 \%$ and $1.82 \%$, respectively, over the 1980 to 1997 period. The number of analysts is available for 6,518 repurchase announcements and the dispersion of analyst forecasts is available for 5,600 repurchase announcements (compared to 8,859 repurchases for which we can calculate CAR). We later use the median number of analysts 
(five) and analyst dispersion (4\%) to bifurcate our sample into low and high information asymmetry groups for long-term abnormal returns calculations.

\section{[Insert Table 1 Here]}

In the appendix, we discuss potential information asymmetry between inside managers and outside investors and how to test this information asymmetry by applying Sims' (1972) two-sided regression based causality test. By using this test and considering different degrees of information asymmetry, we can tell whether inside managers indeed have information advantages over outside investors.

Based on the discussions in the appendix (see Proposition 1, equations (A.11) and (A.12)), the Granger causality in (A.11), which is based on the two-sided regression by Sims (1972, Theorem 2), can be tested based on the usual (equivalent) one-sided Granger-causality tests in (A.12). Therefore, we investigate the relationship between monthly returns and manager's share repurchase announcements using the following regression, where the inclusion of lagged values of market returns helps us to control for potential feedback in share repurchase decisions:

$$
R_{t}=\gamma+\sum_{j=1}^{m} \alpha_{j} R_{t-j}+\sum_{j=1}^{m} b_{j} R E P_{t-j}+\eta_{t^{\prime}}
$$

where $R_{t}$ is the monthly return for a given firm in month t from CRSP. $R E P_{t}$ is the repurchase variable for a given firm in month $t$ which is measured either as an indicator or as a percent of the firm to be repurchased. Specifically, REP is an indicator equal to one if the current month contains a repurchase and is zero otherwise. REP\% is the percent of the firm to be repurchased in a given month and is equal to the dollar value of the repurchase divided by the market value of the firm in a given month. 
To make inferences about potential information asymmetry, we analyze the characteristics of the coefficients. Since this causality test can be interpreted as being based on information asymmetry as discussed above (or as in the appendix), we interpret a finding of a causal relation from share repurchase to market return as evidence of share repurchase decisions based on information asymmetry. Based on the discussions in the appendix, we test whether the individual coefficients of lagged repurchases are zero to see whether share repurchases Granger-cause returns. Share repurchase, REP, is said to Granger-cause return if we reject:

$\mathrm{H}_{0}: b_{j}=0$, for all $\mathrm{j}$ in (2).

In other words, the share repurchase, REP, Granger-causes returns if lagged REP can predict current returns, controlling for past returns. If the null $\mathrm{H}_{0}: b_{j}=0$, for all $\mathrm{j}$ in (2) is rejected, we find evidence of market timing using the share repurchase, REP. This specification also allows us to test the net (cumulative) effect of lagged share repurchase on market returns. Specifically, we test:

$$
\mathrm{H}_{0}: \sum_{j=1}^{m} b_{j}=0 \text { in (2), }
$$

which allows us to test for the sign of the causal relation. If we find the net effect (sum of coefficients, $\sum_{j=1}^{m} b_{j}$ ) is significantly positive, the sign of the causation is consistent with the expectation that managers increase share repurchases in anticipation of an increase in stock return (i.e., market timing).

As discussed above, our measure of information asymmetry is originally based on twosided causality regression (i.e., equation (A.11) in the appendix) developed by Sims (1972). Our time-series model acknowledges information asymmetry between potentially informed managers and other uninformed investors. In this situation, repurchase announcements may contain 
information about future stock returns. Our model ultimately tests the predictive power of repurchase announcements, which we equate to information asymmetry.

The causality regression in (2) is conducted for each firm in the sample and as such, 8,859 $(7,781)$ individual regressions are run using REP (REP\%) over the full time series of available returns. An F-test of the significance of the lagged repurchase terms is conducted and the p-value of this test is used to determine the predictive power of repurchase announcements. If the p-value for an individual regression is less than 0.05 , we conclude that the repurchase announcement is predictive of future returns. The predictive power based on the p-value is then interpreted as a measure of information asymmetry.

Informed repurchases indicate the presence of information asymmetry at the time of the repurchase announcement. This approach differs from other information asymmetry measures such as firm size and those based on analysts (e.g., number of analysts following, and analyst forecast dispersion). While a priori information asymmetry proxies have the advantage of yielding predictions and possibly tradable results, they are limited in the sense that they capture relatively crude elements of information asymmetry. For example, a small firm may indeed have a relatively high degree of information asymmetry, but that fact does not speak to the relative valuation of that firm. Thus, all repurchases by small firms are not necessarily true signals of undervaluation or other relevant inside information that would alleviate information asymmetry issues. In fact, the credibility of repurchase announcements has received considerable scrutiny in the literature. ${ }^{3}$ Our measure has the advantage of providing a more specific measure of information asymmetry that is related to repurchase announcements. Specifically, we determine which share repurchase

${ }^{3}$ See for example Babenko et al. (2012). 
announcements are ultimately predictive of positive future return performance and thus are the most likely cases of relatively high levels of information asymmetry.

\section{Results}

In order to establish which repurchase announcements involve firms with a relatively higher level of information asymmetry, we use firm-by-firm causality regressions of returns and repurchases as discussed in Section 3. A summary of the results from these regressions is provided in Table 2.

In Panel A of Table 2, we regress current period returns on six month lagged returns and six month lagged REP (i.e., $\mathrm{m}=6$ in equation (2)), which is an indicator equal to one if the month contained a repurchase announcement and is zero otherwise. There were 8,883 firms repurchasing during the 1990-2012 period for which we were able to conduct this test. The mean and median pvalues for the effect of the coefficients on the lagged repurchase terms on current returns are 0.62 and 0.71 , respectively. Thus, the mean and median repurchase announcement is relatively uninformed. In fact, only 798 out of 8,883 repurchase announcements are found to have a statistically significant (at a minimum of the 5\% level) predictive ability for lagged repurchases on current returns. Similarly, Dittmar and Field (2013) find that the majority of repurchases are not able to time firm undervaluation.

\section{[Insert Table 2 Here]}

In Panel B of Table 2, we use REP\% as the repurchase variable of interest. REP\% is the dollar amount of the announced repurchase program divided by the market value of the firm. $\mathrm{REP} \%$ is commonly used in the literature and may better capture the relative size of the 
repurchase. ${ }^{4}$ This in turn may provide more specific indications of the information contained in the repurchase announcement. Specifically, one would expect that firms repurchasing a relatively larger proportion of themselves have relatively more information about the value of their firms.

The results in Panel B of Table 2 indicate similar predictive ability of repurchases for future returns to the results in Panel A of Table 2. The mean and median p-values are 0.64 and 0.76 , respectively. Additionally, 679 of the 7,779 firms examined in Panel B of Table 2 are found to have a significant effect of lagged repurchases on current returns. ${ }^{5}$ The results of Panel B verify that most repurchases are not informed.

While Table 2 establishes a measure of firm-level information asymmetry for repurchase announcements, it does not address the market reaction at the time of the announcement. To the extent that efficient markets correctly identify repurchase announcements with the most credible signals (i.e., those involving firms with the highest levels of information asymmetry), we would expect that our information asymmetry measure and abnormal returns would be positively related.

We examine event CARs for repurchasing firms based on levels of information asymmetry in Table 3. Each repurchasing firm is grouped into either the informed or uninformed category based on the p-value from firm-level regressions in Table 2. The informed group contains all firms with p-values less than 0.05 from the causality regressions. Panel A of Table 3 presents the results of tests of differences in mean CAR for repurchasing firms based on whether or not the repurchasing firm is classified as informed. We find, regardless of which definition of repurchase we use, abnormal returns are higher for informed firms than for uninformed firms. The difference

\footnotetext{
${ }^{4}$ See for example Babenko et al. (2012).

${ }^{5}$ The difference in sample size between Panel A and Panel B of Table 2 is due to the availability of the dollar value of repurchases from SDC.
} 
in CAR for the event window is $0.57 \%$ and $1.02 \%$ for REP and REP\%, respectively. Thus, firms with greater information asymmetry show higher announcement returns. This suggests that the market correctly identifies such firms at the time of the announcement. We compare our results to those of Dittmar and Field (2013) who examine repurchase announcement returns based on information asymmetry as measured by analyst following and dispersion measures. They find that firms with greater information asymmetry are more likely to repurchase at relatively low prices, which may explain the relatively more positive market reaction to such announcements.

\section{[Insert Table 3 Here]}

In Panel B of Table 3, we conduct the same analysis except that we now focus only on "small" firms, which we define as firms with below median market value for the sample. ${ }^{6}$ Firm size has been used frequently as a proxy for information asymmetry in the literature previously (Vermaelen, 1981; Corwin, 2003; Zhang, 2006). If firm size completely captures elements of information asymmetry related to repurchases, then splitting on firm size alone may be enough to identify informed repurchases. However, if further splitting the sample based on our information asymmetry measure yields a significant difference in announcement returns between the two groups, then it suggests that our proxy captures information asymmetry which is particularly related to repurchases. We find that the result of Panel A of Table 3 is even stronger in Panel B. Specifically, the announcement return is $1.21 \%$ and $1.42 \%$ higher for informed repurchases using REP and REP\%, respectively, in the sample using only relatively smaller firms, which are between

\footnotetext{
${ }^{6}$ The median market capitalization in our sample is $\$ 224$ million.
} 
roughly $40 \%$ and $100 \%$ larger than the difference in CAR in Panel A. This finding suggests that firm size may not completely capture information asymmetry related to repurchases.

In Panel C of Table 3, we focus only on "large" firms, those with above median market value for our sample. As hypothesized in Panel B, it may be that firm size captures the relevant portions of information asymmetry related to repurchases. However, it may also be true that firm size fails to completely capture information asymmetry in this context. The results in Panel C of Table 3 indicate no significant difference between announcement returns based on our informed indicator for large firms, regardless of the repurchase measure used. Thus, at least amongst larger firms, our information asymmetry proxy does not contribute additional understanding relative to a simple firm size measure.

Overall, this result is perhaps not surprising. To the extent that information amongst larger firms is relatively more homogenous than the dispersion for smaller firms, our results in Panels B and $\mathrm{C}$ are expected. It is also possible that larger firms are relatively more likely to undertake repurchases for reasons other than undervaluation or other information signaling. This is consistent with the fact that announcement returns are substantially lower (i.e., far less than half) across the board for larger firms relative to smaller firms. The larger announcement returns for smaller repurchasing firms is consistent with Chan et al. (2004). Thus, the market in general is less optimistic about the large firm repurchase announcement, which may be due to less new information being generated by such an announcement. Still, our causality regression approach indicates that roughly $8 \%$ of large firm repurchases (using REP\%) are informed and the market does not capture this at the time of the announcement. The literature frequently uses measures 
based on analysts as proxies for information asymmetry. We do not focus on these proxies in Table 3 , but control for them explicitly in the regressions to follow in Table 4 .

Table 4 presents regressions similar in spirit to the analysis in Table 3. Specifically, we present regression results which use event CARs as the dependent variable. The explanatory variables include informed indicators, REP and REP\%. The Informed (REP) or Informed (REP\%) indicates if the informed indicator is based on a repurchase indicator or the relative size of the repurchase. REP is an indicator equal to one if the current month contains a repurchase announcement and is equal to zero otherwise. REP\% is the percent of the firm to be repurchased in a given month and is equal to the dollar value of the repurchase divided by the market value of the firm in a given month. We control for the size of the repurchase (REP\%), firm size (Size), the number of analysts following, and the dispersion of analyst forecasts. In short, we test the relation between our information asymmetry proxy and announcement abnormal returns after controlling for other traditional information asymmetry proxies.

\section{[Insert Table 4 Here]}

Consistent with the difference in means tests in Table 3, the results in Table 4 indicate that the informed indicator is positively related to CAR in all 12 specifications (significant at a minimum of the $10 \%$ level), regardless of the definition of informed (i.e., Informed (REP) or Informed (REP\%)) or the control variables included. We find that repurchase size (REP\%) is positively related to announcement CARs (significant at the $1 \%$ level in all specifications in which it is included). Firm size (Size) is negatively related to announcement CARs (at the $1 \%$ level in all specifications in which it is included). Consistent with Table 3, this suggests that smaller firms show, on average, a higher announcement CAR than larger firms. However, the inclusion of firm 
size (Size) does not mute the significance of our information asymmetry proxy. The number of analysts is negatively related to announcement CARs (at a minimum of 5\% level in all specifications in which it is included). Thus, consistent with other information asymmetry proxies, we find that firms with lower information asymmetry (i.e., higher number of analysts following) show lower announcement CARs. Finally, we find that the coefficient on analyst dispersion is not statistically significant. In specifications (11) and (12), we include repurchase size (REP\%) and all information asymmetry proxies (firm size (Size), number of analysts and analyst dispersion) and our measure of informed repurchases remains significant at the 5\% level. The economic interpretation in specifications (11) and (12) indicates that informed repurchases show a $0.76 \%$ and $0.94 \%$ higher CAR, respectively, after controlling for other information asymmetry proxies. Thus, it does not appear that traditional information asymmetry proxies subsume our repurchase specific information asymmetry measure.

In addition to the size of the repurchase program, the frequency of repurchase announcements may also drive the results documented to this point. This is based on Jagannathan and Stephens (2003) and Dittmar and Field (2013), who note that the motivations of frequent repurchasers may differ from less frequent repurchasers. Specifically, Dittmar and Field (2013) find that firms who repurchase at a higher frequency are not motivated by undervaluation and do not purchase at relatively low prices. In their analysis of information asymmetry, Dittmar and Field (2013) find that firms with greater information asymmetry are better able to purchase at lower 
prices. This suggests that firms that repurchase less frequently are relatively better informed. ${ }^{7} \mathrm{We}$ confirm this in Table 5.

In Table 5 we find the CAR drops as the number of repurchase announcements increases. For instance, the mean CAR for a firm with only one repurchase announcement in the sample is $3.24 \%$ compared to a CAR of $1.58 \%$ for firms repurchasing four times in the sample period. Thus, firms that announce repurchases more often have less informative repurchases.

\section{[Insert Table 5 Here]}

In Table 6 we run regressions in which announcement CAR is the dependent variable, and repurchase informed status (Informed (REP) or Informed (REP\%)), repurchase size (REP\%), repurchase frequency, and traditional measures of firm information asymmetry (i.e., firm size (Size), the number of analysts following, and the dispersion of analyst forecasts) are explanatory variables. Consistent with Table 5, we find that the frequency of repurchase is negatively related to announcement CARs in specifications (1) and (2). However, the inclusion of firm size, the number of analysts and the dispersion of analyst forecasts eliminates the significance of repurchase frequency. Finally, including the frequency of repurchase (and including other information asymmetry proxies) does not change the relation between our informed indicator and CARs. Specifically, consistent with Tables 3 and 4 , the informed indicator is positively related to announcement CARs even after we control for repurchase frequency and other traditional information asymmetry proxies.

\footnotetext{
${ }^{7}$ We note that the frequency of repurchasing in Dittmar and Field (2013) is based on actual repurchases while our measure of repurchase frequency is based on announced repurchases.
} 
[Insert Table 6 Here]

The analysis to this point has focused on the relation between our information asymmetry proxy and announcement abnormal returns. In Table 7, we extend this approach to examine longterm abnormal returns. ${ }^{8}$ This analysis is included to address the potential for factors other than the repurchase announcement to drive future performance. For instance, it could be that repurchases are more likely during certain periods which are likely to be associated with relatively more positive future return performance. The use of long-term abnormal returns controls for systemic factors related to returns. Long-term abnormal returns are calculated using the Fama and French (1993) three factors (see equation (1)). We form equally weighted monthly calendar-time portfolios for the full sample and also for bifurcated samples based on information asymmetry. We report the average monthly abnormal returns and the t-statistic for the event horizons of months $(+1,+12),(+1,+24)$, and $(+1,+36)$ following Peyer and Vermaelen (2009).

We find that for all firms in the sample, the monthly average abnormal returns for the one, two and three year event horizons are positive and statistically significant. The average monthly abnormal return is $0.34 \%, 0.27 \%$, and $0.25 \%$, respectively, for the one, two and three-year windows. This is consistent with the literature documenting a post repurchase drift anomaly. Next, we form portfolios based only on firms in our sample identified as informed based on the regressions in Table 2 . We find that the average monthly abnormal returns for informed firms are

\footnotetext{
${ }^{8}$ Vermaelen (1981) suggests that under the signaling hypothesis, stock repurchase is a measure to transfer the value of information that only the management possesses to current stockholders of the firm, and Vermaelen (1981) also provides evidence that abnormal stock returns remain positive in the long-term. Chan, Ikenberry, Lee, and Wang (2010) argue that earnings quality can be an indicator of false signaling in stock repurchases, because managers sometimes use stock repurchases to manipulate their performance by increasing stock prices. These authors find that firms with low earnings quality are more likely to carry out stock repurchases, but the stock performance of these firms declines in the long-term.
} 
$1.65 \%, 0.84 \%$, and $0.63 \%$, respectively, for the one, two and three-year windows - all of which are significant at the $1 \%$ level. Thus, the economic magnitude of the long-term abnormal returns is between two and four times greater for the sample of informed repurchases compared to the full sample. Results are qualitatively identical regardless of the definition of informed repurchases. These results are perhaps not surprising given that informed repurchases are identified based on regressions of six month lagged repurchases on future returns. Nonetheless, our results indicate that informed repurchases continue to outperform the market and other uninformed repurchases up to three years following the repurchase announcement.

We repeat the portfolio formation process based on median levels of firm size, number of analysts following, and analyst dispersion. In each case, we create two groups. One group with high information asymmetry, the other group with low information asymmetry. Only the firm size bifurcation yields monthly abnormal returns that are greater for the high information asymmetry group while both analyst variables (i.e., number of analysts following and analyst dispersion) yield the opposite result (although economically similar). We find that small firms show average monthly abnormal returns of $0.50 \%, 0.38 \%$, and $0.33 \%$, respectively, for the one, two, and threeyear windows. While these abnormal returns are greater than that of the full-sample, they are between half and one-third the size of the abnormal returns of our measure of informed repurchases. These findings show that our measure of information asymmetry is more strongly related to long-term abnormal returns compared with other traditional information asymmetry proxies.

[Insert Table 7 Here] 
Our proposed proxy for information asymmetry is based on causality tests. This proxy may be related to other conventional information asymmetry proxies after controlling for repurchase size and repurchase frequency. Identifying which, if any, variables are related to our information asymmetry proxy is potentially useful for two reasons. First, we may identify variables that could be used to help predict informed repurchases a priori. Second, examining the extent that our information asymmetry measure is related to other factors may help establish the relative uniqueness of our measure.

In Table 8, we examine the relation between whether or not a repurchase is informed (dependent variable: Informed (REP) or Informed (REP\%)) and other variable such as repurchase size (REP\%), repurchase frequency, firm size (Size), the number of analysts following, and the dispersion of analyst forecasts. While our informed indicator uses a measure of information asymmetry based on causality tests, the analysis in Table 8 may suggest characteristics of informed repurchases that are available a priori.

The results in Table 8 indicate that repurchase size (REP\%) and repurchase frequency are not related to informed repurchases when controlling for information asymmetry proxies (see columns (5) and (6)). When using an indicator of a repurchase in a given month, rather than the relative size of the repurchase, none of the variables considered are related to the informed indicator (see columns (1) and (3)). However, when the informed indicator is based on the relative size of the repurchase (Informed (REP\%)), we find that larger firms (greater analyst dispersion) are negatively (positively) related to informed repurchases (see column (6)). Thus, when the informed indicator is based on the relative size of the repurchase (Informed (REP\%)), firm size and analyst dispersion play a complementary role to this measure of information asymmetry. Both 
firm size and analyst dispersion are available at the time of the repurchase announcement. This may allow investors to correctly identify informed repurchases. However, given the abnormal return analysis performed above, it does not appear as though the market fully responds to truly informed repurchases.

\section{[Insert Table 8 Here]}

\section{Conclusion}

While the initial average response to the announcement of an open market share repurchase is positive, it is less clear which announcements are true signals of positive future performance. The signals from an open market repurchase announcement may be more credible in the case of firms with relatively high levels of information asymmetry. In such a case, the announcement of the repurchase program may bring the level of information possessed by the managers and the shareholders closer together.

We propose a repurchase specific measure of information asymmetry that is based on time series causality tests due to Granger (1969) and Sims (1972). The resulting information asymmetry measure is based on the assumption that if repurchase information predicts future returns, then that repurchase is informed. When we relate our measure of information asymmetry to abnormal returns following the announcement of open market share repurchases, we find that they are positively related. Thus, firms with relatively higher levels of information asymmetry are found to be relatively more informed repurchasers. This result holds when controlling for traditional information asymmetry proxies such as firm size, number of analysts following, and analyst dispersion. Thus, our information asymmetry measure captures information not contained in 
traditional information asymmetry proxies. Finally, we document that our measure of information asymmetry is positively related to long-term abnormal returns for one, two, and three-year windows. 


\section{References}

Babenko, I., Y. Tserlukevich, and A. Vedrashko, 2012, The credibility of open market share repurchase signaling, Journal of Financial and Quantitative Analysis 47, 1049-1088.

Barclay, M., and C. Smith, 1988, Corporate payout policy: cash dividends versus open-market repurchases, Journal of Financial Economics 22, 61-82.

Billett, M., and H. Xue, 2007. The takeover deterrent effect of open market share repurchases, Journal of Finance 62, 1827-1850.

Box, G. E. P. and G. M. Jenkins, 1976, Time series analysis: Forecasting and control, Holden Day.

Brav, A., J.R. Graham, C.R. Harvey, and R. Michaely, 2005, Payout policy in the $21^{\text {st }}$ century, Journal of Financial Economics 77, 483-527.

Brockman, P., D. Chung, 2001, Managerial timing and corporate liquidity: Evidence from actual share repurchases, Journal of Financial Economics 61, 417-448.

Bushman, R., J. Piotroski, and A. Smith, 2004, What determines corporate transparency? Journal of Accounting Research 42, 207-252.

Chan, K., D. Ikenberry, and I. Lee, 2004, Economic sources of gain in stock repurchases, Journal of Financial and Quantitative Analysis 39, 461-479.

Chan, K., D. Ikenberry, I. Lee, and Y. Wang, 2010, Share repurchases as a potential tool to mislead investors, Journal of Corporate Finance 16, 137-158.

Chang, J., T. Khann, and K. Palepu, 2000, Analyst activity around the world. HBS Strategy Unit Working Paper No. 01-061.

Comment, R., and G. A. Jarrell, 1991, The relative signaling power of Dutch-auction and fixedprice self-tender offers and open-market share repurchases, Journal of Finance 46, 1243-1271.

Cook, D., L. Krigman, and C. Leach, 2004, On the timing and execution of open market repurchases, Review of Financial Studies 17, 463-498.

Corwin, S. A., 2003, The determinants of underpricing for seasoned equity offers, Journal of Finance 58, 2249-2279.

Denis, D., 1990, Defensive changes in corporate payout policy: share repurchases and special dividends, Journal of Finance 45, 1433-1456. 
Diether, K. B., C. J. Malloy, and A. Scherbina, 2002, Difference of opinion and the cross-section of stock returns, Journal of Finance 57, 2113-2141.

Dittmar, A.K., 2000, Why do firms repurchase stock? Journal of Business 73, 331.

Dittmar, A., and L. Field, 2013, Can managers time the market? Evidence using repurchase price data, Working Paper, University of Michigan and Pennsylvania State University.

Fama, E. F. and K. French, 1993, Common risk factors in the returns on stocks and bonds, Journal of Financial Economics 33:1, 3-56.

Fenn, G. W., and N. Liang, 2001, Corporate payout policy and managerial stock incentives, Journal of Corporate Finance 60, 45-72.

Fuller W., 1976. Introduction to Statistical Time Series. New York: John Wiley.

Granger, C. W. J., 1969, Investigating causal relations by econometric models and cross-spectral methods, Econometrica 37, 424-438.

Granger, C. W. J. and P. Newbold, 1986, Forecasting Economic Time Series, $2^{\text {nd }}$ edition, Academic Press.

Grullon, G., and R. Michaely, 2002, Dividends, share repurchases, and the substitution hypothesis, Journal of Finance 57, 1649-1684.

Grullon, G., and R. Michaely, 2004, The information content of share repurchase programs, Journal of Finance 59, 651-680.

Guay, W., and J. Harford, 2000, The cash-flow permanence and information content of dividend increases versus repurchases, Journal of Financial Economics 57, 385-415.

Hong, H., T. Lim, and J. C. Stein, 2000, Bad news travels slowly: Size, analyst coverage, and the profitability of momentum strategies, Journal of Finance 55, 265-295.

Ikenberry, D., J. Lakonishok, and T. Vermaelen, 1995, Market underreaction to open market share repurchases, Journal of Financial Economics 39, 181-208.

Jagannathan, M., C. Stephens, and M.S. Weisbach, 2000. Financial flexibility and the choice between dividends and share repurchases, Journal of Financial Economics 57, 355-384.

Jagannathan, M., and C. Stephens, 2003, Motives for multiple open-market repurchase programs, Financial Management 32, 71-91.

Jensen, M.C., 1986, Agency costs of free cash flow, Corporate finance, and takeovers, American Economic Review 76, 323-329. 
Jolls, C., 1998, Stock repurchases and executive compensation, Harvard Law School Working Paper.

Jun, S.G., M. Jung, and R.A. Walkling, 2009, Share repurchase, executive options and wealth change to stockholders and bondholders, Journal of Corporate Finance 15, 212-229.

Kahle, K.M., 2002. When a buyback isn't a buyback: open market repurchases and employee options, Journal of Financial Economics 63, 235-261.

Krishnaswami, S., and V. Subramaniam, 1999, Information asymmetry, valuation, and the corporate spinoff decision, Journal of Financial Economics 53, 73-112.

Lee, B.S., and O.M. Rui, 2007, Time-series behavior of share repurchases and dividends, Journal of Financial and Quantitative Analysis 42, 119-142.

Louis, H., and H. White, 2007, Do managers intentionally use repurchase tender offers to signal private information? Evidence from firm financial reporting behavior, Journal of Financial Economics 85 (2007), 205-233.

Peyer, U., and T. Vermaelen, 2009, The nature and persistence of buyback anomalies, Review of Financial Studies 22, 1693-1745.

Sims, C.A.., 1972, Money, income, and causality, American Economic Review 62, 540-552.

Vermaelen, T., 1981, Common stock repurchases and market signaling, Journal of Financial Economics 9, 139-183.

Yook, K.C., 2010, Long-run stock performance following stock repurchases, Quarterly Review of Economics and Finance 50, 323-331.

Zhang, X. F., 2006, Information uncertainty and stock returns, Journal of Finance 61, 105-137. 


\section{Appendix:}

\section{Empirical model of a test of asymmetric information based on causality tests (Sims test)}

In this appendix, we provide a simple, parsimonious time-series model in which there is potential information asymmetry between informed inside managers and outside investors so that we can draw inferences about the market's reactions to share repurchase announcements. In such a case, share repurchase decisions by inside managers may contain (or convey) new information about future stock returns. In fact, some share repurchase decisions may be information events (i.e., forward-looking), while others may be non-information events (i.e., backward-looking) with respect to stock returns. The share repurchase decision will be related to future stock returns when it is an informative event under information asymmetry. The idea is that although informed inside managers and uninformed outside investors observe the same financial variables such as current and past stock returns and fundamentals, uninformed outside investors may not fully recover all the information which informed inside managers use in share repurchase. ${ }^{9}$ Our model is useful because it provides a regression model that tests the predictive power of share repurchase under potential information asymmetry.

Here, we utilize a theorem in time-series econometrics, which states that any time-series process has both invertible and non-invertible representations [see Fuller (1976, P. 64-66, Theorem 2.6.4)]. Although stock returns may follow a general ARMA (autoregressive moving average) process, for expositional simplicity we assume that uninformed outside investors, observing current and past stock returns, infer a first-order moving average, MA(1), process of the returns: 10

$$
\mathrm{R}_{\mathrm{t}}=(1-\lambda \mathrm{L}) \mathrm{u}_{\mathrm{t}}, \quad|\lambda|<1.0
$$

where $R_{t}$ is the stock return at time $t, L$ is the lag (or backshift) operator (i.e., $L^{n} R_{t}=R_{t-n}$ ), and $u_{t}$ is white noise with $\operatorname{var}\left(\mathrm{u}_{\mathrm{t}}\right)=\sigma_{\mathrm{u}}{ }^{2}$. The autocovariance functions (ACFs) for this return process are:

$$
\begin{aligned}
& \operatorname{var}\left(R_{t}\right)=\left(1+\lambda^{2}\right) \sigma_{u}^{2}, \\
& \operatorname{cov}\left(R_{t}, R_{t-1}\right)=-\lambda \sigma_{u}^{2}, \\
& \operatorname{cov}\left(R_{t}, R_{t-k}\right)=0, \text { for } k \geq 2
\end{aligned}
$$

\footnotetext{
${ }^{9} \mathrm{We}$ can capture this intuition in a time-series concept of the non-invertibility of the moving average representation [see Box and Jenkins (1976, p.69) and Granger and Newbold (1986, p.145)].

${ }_{10}$ Any higher-order representation of returns yields the same dynamic relationships with more complicated computations.
} 
Conversely, suppose that informed inside managers, observing the same current and past stock returns, infer the following $\mathrm{MA}(1)$ process of the returns:

$$
\mathrm{R}_{\mathrm{t}}=\left(1-\lambda^{-1} \mathrm{~L}\right) \mathrm{v}_{\mathrm{t}}, \quad|\lambda|<1.0,
$$

where $\mathrm{v}_{\mathrm{t}}$ is white noise with $\operatorname{var}\left(\mathrm{v}_{\mathrm{t}}\right)=\sigma_{\mathrm{v}}{ }^{2}$. The ACFs for this return process are:

$$
\begin{aligned}
& \operatorname{var}\left(R_{t}\right)=\left(1+\lambda^{-2}\right) \sigma_{\mathrm{v}}^{2}, \\
& \operatorname{cov}\left(R_{t}, R_{t-1}\right)=-\lambda^{-1} \sigma_{v}^{2}, \\
& \operatorname{cov}\left(R_{t}, R_{t-k}\right)=0, \text { for } \mathrm{k} \geq 2 .
\end{aligned}
$$

Note that if we set $\sigma_{\mathrm{v}}{ }^{2}=\lambda^{2} \sigma_{\mathrm{u}}{ }^{2}$, the ACFs in (A.2) and (A.4) are identical. Since the return process can be identified in practice only by the observed ACFs, the identical ACFs imply that stock return processes in (A.1) and (A.3) represent the same return process. That is, for a given return process, outside investors and inside managers may infer different MA(1) processes. ${ }^{11}$ In addition, $\sigma_{\mathrm{v}}{ }^{2}$ is smaller than $\sigma_{u}^{2}$ because

$$
\sigma_{\mathrm{v}}^{2}=\lambda^{2} \sigma_{\mathrm{u}}^{2}, \quad \text { and } \quad|\lambda|<1.0 \text {. }
$$

This means that the variance of the one-step-ahead forecast error of the return process in (A.3) by inside managers would be smaller than the corresponding variance of the return process in (A.1) by uninformed outside investors. However, unlike the $u_{t}$ process, the $v_{t}$ process cannot be recovered by uninformed investors using information about current and past values of stock returns. In sum, although both inside managers and outside investors observe the same (current and past) returns, under information asymmetry informed inside managers with a larger information set $\Omega_{\mathrm{t}}{ }^{*}=\left\{\mathrm{R}_{\mathrm{t}-\mathrm{j}}, \mathrm{v}_{\mathrm{t}-\mathrm{j}}, \mathrm{u}_{\mathrm{t}-\mathrm{j}}\right.$, for $\left.\mathrm{j} \geq 0\right\}$ can forecast future returns better than uninformed investors with a smaller information set $\Omega_{t}=\left\{R_{t-j}, u_{t-j}\right.$, for $\left.j \geq 0\right\}$.

We can gain an important alternative insight by comparing the corresponding autoregressive representations (ARR) of the moving average representations (MAR) of stock return processes $\left\{R_{t}\right\}$ in (A.1) and (A.3):

$$
\begin{aligned}
& \mathrm{u}_{\mathrm{t}}=(1-\lambda \mathrm{L})^{-1} \mathrm{R}_{\mathrm{t}}=\sum_{\mathrm{j}=0}^{\infty} \lambda^{\mathrm{j}} \mathrm{R}_{\mathrm{t}-\mathrm{j}}, \text { and } \\
& \mathrm{v}_{\mathrm{t}}=\left(1-\lambda^{-1} \mathrm{~L}\right)^{-1} \mathrm{R}_{\mathrm{t}}=-\left(\lambda \mathrm{L}^{-1}\right)\left(1-\lambda \mathrm{L}^{-1}\right)^{-1} \mathrm{R}_{\mathrm{t}}=-\sum_{\mathrm{j}=1}^{\infty} \lambda^{\mathrm{j}} \mathrm{R}_{\mathrm{t}-\mathrm{j}} .
\end{aligned}
$$

\footnotetext{
${ }^{11}$ The return process in (A.1) with the innovation $u_{t}$ is an invertible MAR because the root of the determinant of the MAR of $R_{t}$ is greater than 1 (i.e., det $[1-\lambda z]=0$, for $z=\lambda^{-1}$ ). However, the return process with the innovations $v_{t}$ in (A.3) is a non-invertible MAR because the root of the determinant is less than 1 (i.e., $\operatorname{det}\left[1-\lambda^{-1} z\right]=0$, for $z=\lambda$ ).
} 
Note that the innovations $\left\{\mathrm{u}_{\mathrm{t}}\right\}$ in the uninformed outside investors' return process are backwardlooking, whereas the innovations $\left\{\mathrm{v}_{\mathrm{t}}\right\}$ in the informed inside managers' return process are forwardlooking.

How is this information asymmetry between inside managers and outside investors related to the dynamic relationship between share repurchase decisions by inside managers and stock returns (i.e., the predictive power of stock sales)? Suppose that inside managers have an information advantage in that they can forecast the firm's future prospects better than uninformed investors by observing $\mathrm{v}_{\mathrm{t}}$. If inside managers apply this information to their share repurchase decisions, their share repurchase decision, $\mathrm{REP}_{t}$, will be a function of the innovation $\mathrm{v}_{t}$ that they observe but uninformed outside investors do not:

$$
R E P_{t}=f\left(v_{t}\right)=\sum_{i=0}^{\infty}\left(\theta_{i} L^{i}\right) v_{t}=\sum_{i=0}^{\infty} \theta_{i} v_{t-i}, \text { with } \sum_{i=0}^{\infty} \theta_{i}^{2}<\infty
$$

Then, by using $\mathrm{v}_{\mathrm{t}}$ in (A.6), the share repurchase variable, $\mathrm{REP}_{\mathrm{t}}$, and stock return processes will be related as follows:

$$
R E P_{t}=\sum_{i=0}^{\infty}\left(\theta_{i} L^{i}\right)\left\{\left(1-\lambda^{-1} L\right)^{-1} R_{t}\right\}=\sum_{i=0}^{\infty}\left(\theta_{i} L^{i}\right)\left(-\sum_{j=1}^{\infty} \lambda^{j} R_{t+j}\right)=\sum_{j=-\infty}^{\infty} \delta_{j} R_{t-j}
$$

where $\delta_{\mathrm{j}}$ for $\mathrm{j}=-\infty, \ldots,-2,-1,0,1,2, \ldots \infty$ is a function of $\theta_{\mathrm{i}}$ and $\lambda^{\mathrm{j}}$. That is, the share repurchase will be a linear combination of future, current, and past returns; thus, it will be forward-looking. In practice, since inside managers do not have perfect foresight, (A.7.2) will be

$$
R E P_{t}=\sum_{j=0}^{\infty} \delta_{j} R_{t-j}+E_{t}\left[\sum_{j=-\infty}^{-1} \delta_{j} R_{t-j}\right]
$$

In contrast, suppose that inside managers do not have an information advantage or they simply do not make share repurchase decisions based on their information advantage. Then, the share repurchase will be a function of $u_{t}$, the innovation that uninformed outside investors observe:

$$
R E P_{t}=f\left(u_{t}\right)=\sum_{i=0}^{\infty}\left(\theta_{i} L^{i}\right) u_{t}=\sum_{i=0}^{\infty}\left(\theta_{i} u_{t-1}\right) \text {, with } \sum_{i=0}^{\infty} \theta^{2}<\infty .
$$

Then, by using $\mathrm{u}_{\mathrm{t}}$ in (A.6), stock sale and stock return processes will be related as follows:

$$
R E P_{t}=\sum_{i=0}^{\infty}\left(\theta_{i} L^{i}\right)(1-\lambda L)^{-1} R_{t}=\sum_{i=0}^{\infty}\left(\theta_{i} L^{i}\right)\left\{\sum_{j=0}^{\infty} \lambda^{j} R \quad t-j\right\}=\sum_{k=0}^{\infty} \delta_{k} R_{t-k},
$$

where $\delta_{k}$ for $\mathrm{k}=0,1,2, \ldots \infty$ is a function of $\theta_{\mathrm{i}}$ and $\lambda^{\mathrm{j}}$. That is, in this case the share repurchase will only reflect the past and current returns and will not be related to future returns; thus, it will be backward-looking. To summarize, we have shown that under information asymmetry, informative share repurchase decisions are related to not only past and present returns but also future returns. By contrast, in the absence of information asymmetry, non-informative share repurchase decisions are not related to future returns. 
A practical question is how we distinguish between the two -- informative and noninformative -- types of share repurchase decisions. When an inside manager makes share repurchase decision, if it contains new information about future prospects of the firm (i.e., stock returns) that is not contained in the current and past values of returns and share repurchase, it is an informative (i.e., forward-looking) share repurchase and it is related to future returns. Otherwise, it is a non-informative (i.e., backward-looking) share repurchase. We can empirically test whether share repurchase decisions are informative or not by using the following proposition.

The equivalence of the two-sided regression in (A.7.2) with Granger causality has been established by Sims (1972, Theorem 2), which we restate in our context:

\section{Proposition 1. Consider the following two-sided regression:}

$$
R E P_{t}=\alpha+\sum_{j=-m}^{m} \delta_{j} R_{t-j}+\varepsilon_{t}
$$

where $\mathrm{E}\left(\varepsilon_{\mathrm{t} .} \mathrm{R}_{\mathrm{t}-\mathrm{j}}\right)=\mathbf{0}$ for all $\mathbf{j}(=-\mathrm{m} . \ldots-1,0,1, \ldots \mathrm{m})$. If the null hypothesis that all the coefficients of future returns are zero (i.e., $\delta_{j}=\mathbf{0}$ for all $\mathbf{j}<\mathbf{0}$ ) is rejected, then $S_{t}$ Grangercauses $R_{\text {t. }}$.

That is, we can use the two-sided regression as a means of testing the predictability of share repurchase for market returns, and the finding of the predictive power of stock sale can be interpreted based on information asymmetry.

Equivalently, the Granger causality in (A.11), which is based on the two-sided regression by Sims (1972, Theorem 2), can be tested by the null hypothesis that $\delta_{j}=0$ for all $\mathrm{j}<0$ based on the following regression, which is based on usual (equivalent) one-sided Granger-causality tests:

$$
R_{t}=\gamma+\sum_{j=1}^{m} \alpha_{j} R_{t-j}+\sum_{j=1}^{m} b_{j} R E P_{t-j}+\eta_{t}
$$

That is, we can use a one-sided Granger causality test in (A.12) as a means of testing the predictability of the share repurchase for stock market returns, and the finding of the predictive power of the share repurchase can be interpreted based on information asymmetry. The intuition behind this test is that including lagged values of market returns helps us to control for potential feedback in share repurchase decisions. 


\section{Table 1. Announcement Returns and Summary Statistics}

REP\% is the dollar value of the announced repurchase program divided by firm market capitalization. Value of Transaction is the dollar value of the repurchase in millions of dollars. CAR $(-1,+1)$ is the cumulative abnormal return over the period one day prior to the announced repurchase to one day after the announcement. Number of Analysts is the number of analysts following the firm at the time of the announcement from IBES. Analyst Dispersion is the standard deviation of analyst estimates at the time of the repurchase announcement from IBES. The abnormal returns are calculated using a market model with the estimation window of $(-252,-44)$.

\begin{tabular}{lrrrrrr}
\hline & $\mathrm{N}$ & Mean & Median & Min & Max & S.D. \\
\hline REP\% & 8,232 & $8.59 \%$ & $5.90 \%$ & $0.72 \%$ & $100 \%$ & 9.53 \\
Value of Transaction (Mil) & 8,247 & 168.38 & 14.97 & 0 & 36,200 & 888.63 \\
CAR (-1, +1) & 8,859 & $2.77 \%$ & $1.78 \%$ & $-13.11 \%$ & $22.82 \%$ & 8.40 \\
Number of Analysts & 6,518 & 7.94 & 5.00 & 1.00 & 44.00 & 7.36 \\
Analyst Dispersion & 5,600 & $7.49 \%$ & $4.00 \%$ & $0 \%$ & $34.00 \%$ & $8.78 \%$ \\
\hline
\end{tabular}




\section{Table 2. Firm by Firm Regressions}

This table presents the results of regressions for each firm having completed a repurchase over the period 1990-2012. All available firm-months are included in the sample. $\mathrm{R}$ is the monthly return for a given firm in month $t$ from CRSP. REP is an indicator equal to one if the current month contains a repurchase announcement and is equal to zero otherwise. REP\% is the percent of the firm to be repurchased in a given month and is equal to the dollar value of the repurchase divided by the market value of the firm in a given month.

Panel A: REP Regression

$R_{t}=\gamma+\sum_{j=1}^{6} \alpha_{j} R_{t-j}+\sum_{j=1}^{6} b_{j} R E P_{t-j}$

\begin{tabular}{lrrrrrr}
\hline & $\mathrm{N}$ & Mean & Median & Min & Max & S.D. \\
\hline F-Stat (REP) & 8,833 & 0.93 & 0.62 & 0.04 & 5.64 & 0.99 \\
P-Value (REP) & 8,833 & 0.62 & 0.71 & 0 & 0.99 & 0.34 \\
Significant (REP) $(\mathrm{p}<.05)$ & 798 & & & & & \\
Not Significant (REP) $(\mathrm{p}>=.05)$ & 8,035 & & & & & \\
\hline
\end{tabular}

Panel B: REP\% Regression

$R_{t}=\gamma+\sum_{j=1}^{6} \alpha_{j} R_{t-j}+\sum_{j=1}^{6} b_{j} R E P \%_{t-j}$

\begin{tabular}{lrrrrrr}
\hline & $\mathrm{N}$ & Mean & Median & Min & Max & S.D. \\
\hline F-Stat (REP\%) & 7,779 & 0.91 & 0.56 & 0.03 & 5.76 & 1.03 \\
P-Value (REP\%) & 7,779 & 0.64 & 0.76 & 0 & 0.99 & 0.34 \\
Significant (REP\%) $(\mathrm{p}<.05)$ & 679 & & & & & \\
$\begin{array}{l}\text { Not Significant }(\text { REP\%) } \\
(\mathrm{p}>=.05)\end{array}$ & 8,154 & & & & & \\
\hline
\end{tabular}




\section{Table 3. Abnormal Returns and Information Asymmetry}

This table presents the results of difference in means tests for each firm having completed a repurchase over the period 1990-2012. The announcement abnormal return for the repurchasing firm is compared between informed repurchases and non-informed repurchases. CAR $(-1,+1)$ is the cumulative abnormal return over the period one day prior to the announced repurchase to one day after the announcement. The abnormal returns are calculated using a market model with the estimation window of $(-252,-44)$. Informed is an indicator equal to one if the firm causality regression yielded a p-value of $<0.05$ for the six months lagged terms for repurchases. The (REP) or (REP\%) next to Informed indicates if the informed indicator is based on a repurchase indicator or the relative size of the repurchase. SMALL is an indicator equal to one if the market value of the firm at the time of the repurchase announcement is below the median and is zero otherwise. REP is an indicator equal to one if the current month contains a repurchase announcement and is equal to zero otherwise. REP\% is the percent of the firm to be repurchased in a given month and is equal to the dollar value of the repurchase divided by the market value of the firm in a given month. ${ }^{* * * * * *}$, and * represent statistical significance at the $1 \%, 5 \%$, and $10 \%$ level, respectively.

Panel A: All Firms

\begin{tabular}{lccc}
\hline & Mean CAR & Median & $\mathrm{N}$ \\
\hline Informed (REP) & $3.29 \%$ & $2.16 \%$ & 798 \\
Uninformed (REP) & $2.72 \%$ & $1.77 \%$ & 8,035 \\
Difference (REP) & $0.57 \% *$ & $0.39 \%$ & \\
& & & \\
Informed (REP\%) & $3.74 \%$ & $2.32 \%$ & 679 \\
Uninformed (REP\%) & $2.72 \%$ & $1.82 \%$ & 7,100 \\
Difference (REP\%) & $1.02 \% * * *$ & $0.50 \% * *$ & \\
\hline
\end{tabular}

Panel B: Small Firms

\begin{tabular}{lccc}
\hline & Mean CAR & Median & $\mathrm{N}$ \\
\hline Informed (REP) & $5.14 \%$ & $3.39 \%$ & 397 \\
Uninformed (REP) & $3.93 \%$ & $2.73 \%$ & 4,008 \\
Difference (REP) & $1.21 \% * *$ & $0.66 \% *$ & \\
& & & \\
Informed (REP\%) & $5.43 \%$ & $3.69 \%$ & 357 \\
Uninformed (REP\%) & $4.01 \%$ & $2.86 \%$ & 3,492 \\
Difference (REP\%) & $1.42 \% * * *$ & $0.83 \% * *$ & \\
\hline
\end{tabular}


Panel C: Large Firms

\begin{tabular}{lccc}
\hline & Mean CAR & Median & $\mathrm{N}$ \\
\hline Informed (REP) & $1.45 \%$ & $0.79 \%$ & 401 \\
Uninformed (REP) & $1.52 \%$ & $1.11 \%$ & 4,027 \\
Difference (REP) & $-0.07 \%$ & $-0.32 \%$ & \\
& & & 322 \\
Informed (REP\%) & $1.88 \%$ & $1.06 \%$ & 3,608 \\
Uninformed (REP\%) & $1.46 \%$ & $1.13 \%$ & \\
Difference (REP\%) & $0.42 \%$ & $-0.07 \%$ & \\
\hline
\end{tabular}




\section{Table 4. Abnormal Returns and Information Asymmetry Regressions}

This table presents the results of regressions for each firm having completed a repurchase over the period 1990-2012. The announcement abnormal return for the repurchasing firm is the dependent variable. Specifically, CAR $(-1,+1)$ is the dependent variable and is the cumulative abnormal return over the period one day prior to the announced repurchase to one day after the announcement. The abnormal returns are calculated using a market model with the estimation window of $(-252,-44)$. Informed is an indicator equal to one if the firm causality regression yielded a $p$-value of $<0.05$ for the six months lagged terms for repurchases. The (REP) or (REP\%) next to Informed indicates if the informed indicator is based on a repurchase indicator or the relative size of the repurchase: REP is an indicator equal to one if the current month contains a repurchase announcement and is equal to zero otherwise. REP\% is the percent of the firm to be repurchased in a given month and is equal to the dollar value of the repurchase divided by the market value of the firm in a given month. REP\% is also used for repurchase size. Size is the market value of the firm at the time of the repurchase. No. of Analysts is the number of analysts following the firm at the time of the announcement from IBES. Anal. Dispersion is the standard deviation of analyst estimates at the time of the repurchase announcement from IBES. ${ }^{* * *}, * *$, and ${ }^{*}$ represent statistical significance at the $1 \%, 5 \%$, and $10 \%$ level, respectively.

\begin{tabular}{|c|c|c|c|c|c|c|c|c|c|c|c|c|}
\hline & $(1)$ & (2) & (3) & (4) & $(5)$ & (6) & (7) & $(8)$ & (9) & $(10)$ & $(11)$ & (12) \\
\hline \multirow[t]{2}{*}{ Informed (REP) } & $0.558^{*}$ & & $0.704^{* *}$ & & $0.653^{* *}$ & & $0.819^{* *}$ & & $0.841^{* *}$ & & $0.760 * *$ & \\
\hline & $(0.311)$ & & $(0.315)$ & & $(0.310)$ & & $(0.346)$ & & $(0.367)$ & & $(0.363)$ & \\
\hline \multirow[t]{2}{*}{ Informed (REP\%) } & & $1.019 * * *$ & & $0.960 * * *$ & & $0.815^{* *}$ & & $1.018 * * *$ & & $1.121 * * *$ & & $0.941 * *$ \\
\hline & & $(0.330)$ & & $(0.329)$ & & $(0.325)$ & & $(0.367)$ & & $(0.392)$ & & $(0.388)$ \\
\hline \multirow[t]{2}{*}{ REP\% } & & & $13.207 * * *$ & $13.439 * * *$ & $9.477 * * *$ & $9.568 * * *$ & $10.112 * * *$ & $10.362 * * *$ & $10.792 * * *$ & $11.117 * * *$ & $8.414 * * *$ & $8.621^{* * * *}$ \\
\hline & & & (1.694) & (1.747) & (1.689) & (1.741) & (1.898) & (1.968) & $(2.063)$ & $(2.147)$ & $(2.052)$ & $(2.133)$ \\
\hline \multirow[t]{2}{*}{ Size } & & & & & $-0.731 * * *$ & $-0.758 * * *$ & & & & & $-0.834 * * *$ & $-0.878 * * *$ \\
\hline & & & & & $(0.048)$ & $(0.050)$ & & & & & $(0.089)$ & $(0.093)$ \\
\hline \multirow[t]{2}{*}{ No. of Analysts } & & & & & & & $-0.100 * * *$ & $-0.107 * * *$ & & & $0.043^{* *}$ & $0.044 * *$ \\
\hline & & & & & & & $(0.013)$ & $(0.014)$ & & & $(0.020)$ & $(0.021)$ \\
\hline \multirow[t]{2}{*}{ Anal. Dispersion } & & & & & & & & & 1.246 & 0.761 & 1.301 & 0.719 \\
\hline & & & & & & & & & (1.207) & (1.251) & (1.195) & $(1.238)$ \\
\hline \multirow[t]{2}{*}{ Constant } & $2.724 * * *$ & $2.718 * * *$ & $1.672 * * *$ & $1.683 * * *$ & $6.053 * * *$ & $6.203 * * *$ & $2.421 * * *$ & $2.472 * * *$ & $1.273 * * *$ & $1.302 * * *$ & $6.362 * * *$ & $6.659 * * *$ \\
\hline & $(0.093)$ & (0.098) & $(0.161)$ & $(0.166)$ & $(0.329)$ & $(0.340)$ & $(0.210)$ & $(0.218)$ & $(0.202)$ & $(0.209)$ & $(0.518)$ & $(0.538)$ \\
\hline Observations & 8,845 & 7,790 & 8,203 & 7,789 & 8,203 & 7,789 & 6,388 & 6,044 & 5,497 & 5,185 & 5,497 & 5,185 \\
\hline R-squared & 0.000 & 0.001 & 0.008 & 0.009 & 0.035 & 0.037 & 0.015 & 0.016 & 0.006 & 0.007 & 0.028 & 0.031 \\
\hline
\end{tabular}




\section{Table 5. Abnormal Returns and Repurchase Frequency}

CAR $(-1,+1)$ is the cumulative abnormal return over the period one day prior to the announced repurchase to one day after the announcement. The abnormal returns are calculated using a market model with the estimation window of $(-252,-44)$. The reported results are based on the number of repurchases a given firm has announced during the sample period 1990-2012.

\begin{tabular}{lrrrr}
\hline & One Rep & Two Rep & Three Rep & Four Rep \\
\hline CAR $(-1,+1)$ & $3.24 \%$ & $2.46 \%$ & $1.92 \%$ & $1.58 \%$ \\
$\mathrm{~N}$ & 4,495 & 3,074 & 1,110 & 212 \\
\hline
\end{tabular}




\section{Table 6. Information Asymmetry and Repurchase Frequency Regressions}

This table presents the results of regressions for each firm having completed a repurchase over the period 1990-2012. The announcement abnormal return for the repurchasing firm is the dependent variable. Specifically, CAR $(-1,+1)$ is the dependent variable and is the cumulative abnormal return over the period one day prior to the announced repurchase to one day after the announcement. The abnormal returns are calculated using a market model with the estimation window of $(-252,-44)$. Informed is an indicator equal to one if the firm causality regression yielded a p-value of $<0.05$ for the six months lagged terms for repurchases. The (REP) or (REP\%) next to Informed indicates if the informed indicator is based on a repurchase indicator or the relative size of the repurchase. REP\% is the percent of the firm to be repurchased in a given month and is equal to the dollar value of the repurchase divided by the market value of the firm in a given month, and used for repurchase size. Rep. Freq. is the number of repurchase programs announced by a given firm during the sample period. Size is the market value of the firm at the time of the repurchase. No. of Analysts is the number of analysts following the firm at the time of the announcement from IBES. Anal. Dispersion is the standard deviation of analyst estimates at the time of the repurchase announcement from IBES. ${ }^{* *}, * *$, and ${ }^{*}$ represent statistical significance at the $1 \%, 5 \%$, and $10 \%$ level, respectively.

\begin{tabular}{|c|c|c|c|c|}
\hline & $(1)$ & (2) & (3) & (4) \\
\hline Informed (REP) & $\begin{array}{l}0.689 * * \\
(0.314)\end{array}$ & & $\begin{array}{c}0.758 * * \\
(0.363)\end{array}$ & \\
\hline Informed (REP\%) & & $\begin{array}{c}0.902 * * * \\
(0.329)\end{array}$ & & $\begin{array}{c}0.923 * * \\
(0.388)\end{array}$ \\
\hline REP\% & $\begin{array}{c}12.672 * * * \\
(1.695)\end{array}$ & $\begin{array}{c}12.893 * * * \\
(1.748)\end{array}$ & $\begin{array}{c}8.401 * * * \\
(2.052)\end{array}$ & $\begin{array}{c}8.602 * * * \\
(2.133)\end{array}$ \\
\hline Rep. Freq. & $\begin{array}{c}-0.597 * * * * \\
(0.115)\end{array}$ & $\begin{array}{c}-0.617 * * * * \\
(0.123)\end{array}$ & $\begin{array}{l}-0.128 \\
(0.133)\end{array}$ & $\begin{array}{l}-0.157 \\
(0.142)\end{array}$ \\
\hline Size & & & $\begin{array}{c}-0.820 * * * \\
(0.091)\end{array}$ & $\begin{array}{c}-0.864 * * * \\
(0.094)\end{array}$ \\
\hline No. of Analysts & & & $\begin{array}{c}0.045^{* *} * \\
(0.020)\end{array}$ & $\begin{array}{c}0.046^{* *} \\
(0.021)\end{array}$ \\
\hline Anal. Dispersion & & & $\begin{array}{l}1.165 \\
(1.204)\end{array}$ & $\begin{array}{c}0.544 \\
(1.248)\end{array}$ \\
\hline Constant & $\begin{array}{c}2.713 * * * \\
(0.257)\end{array}$ & $\begin{array}{c}2.734 * * * \\
(0.267)\end{array}$ & $\begin{array}{c}6.495 * * * \\
(0.537)\end{array}$ & $\begin{array}{c}6.836 * * * \\
(0.561)\end{array}$ \\
\hline Observations & 8,203 & 7,789 & 5,497 & 5,185 \\
\hline R-squared & 0.011 & 0.012 & 0.028 & 0.031 \\
\hline
\end{tabular}




\section{Table 7. Long-term Abnormal Returns and Information Asymmetry}

This table presents long-term abnormal return results based on various definitions of information asymmetry. Mon. AR is the monthly average abnormal returns of equally weighted calendar-time portfolios using the Fama-French (1993) three-factor model. Each firm that has announced an open market repurchase during the last, 12, 24, or 36 months (depending on the window examined) forms the calendar-month portfolio. A time-series regression is run in which the dependent variable is excess return and the return on the three factors are the independent variables (market excess return, high-minus-low, and small-minusbig). Different samples are created prior to portfolio formation based on various information asymmetry measures as follows. Informed (Uninformed) refers to firms for which the causality regression yielded a pvalue of $<0.05(>=0.05)$ for the six months lagged terms for repurchases. The (REP) or (REP\%) next to Informed indicates if the informed indicator is based on a repurchase indicator or the relative size of the repurchase. Small (Large) refers to firms below (above or equal to) the median market value of firms in our sample at the time of the repurchase. Low Analyst (High Analyst) refers to firms with above (below or equal to) the median number of analysts following the firm at the time of the announcement from IBES. High Dispersion (Low Dispersion) refers to firms with above (below or equal to) median standard deviation of analyst estimates at the time of the repurchase announcement from IBES. ${ }^{* * *, * *}$, and ${ }^{*}$ represent statistical significance at the $1 \%, 5 \%$, and $10 \%$ level, respectively.

\begin{tabular}{|c|c|c|c|c|c|c|}
\hline & \multicolumn{2}{|c|}{ Months $(+1,+12)$} & \multicolumn{2}{|c|}{ Months $(+1,+24)$} & \multicolumn{2}{|c|}{ Months $(+1,+36)$} \\
\hline & Mon. AR & T-Stat & Mon. AR & T-Stat & Mon. AR & T-Stat \\
\hline Full Sample & $0.34 \%$ & $2.28 * *$ & $0.27 \%$ & $1.93 *$ & $0.25 \%$ & $1.87 *$ \\
\hline Informed (REP) & $1.65 \%$ & $4.51 * * *$ & $0.84 \%$ & $3.49 * * *$ & $0.63 \%$ & $2.99 * * *$ \\
\hline Uninformed (REP) & $0.20 \%$ & $1.80 *$ & $0.21 \%$ & $1.99 * *$ & $0.21 \%$ & $2.08^{* *}$ \\
\hline Informed (REP\%) & $1.65 \%$ & $4.45^{* * *}$ & $0.90 \%$ & $3.84 * * *$ & $0.72 \%$ & $3.48^{* * * *}$ \\
\hline Uninformed (REP\%) & $0.24 \%$ & $1.68 *$ & $0.22 \%$ & 1.60 & $0.22 \%$ & 1.65 \\
\hline Small & $0.50 \%$ & $3.12 * * *$ & $0.38 \%$ & $2.64 * * *$ & $0.33 \%$ & $2.47 * *$ \\
\hline Large & $0.09 \%$ & 0.64 & $0.15 \%$ & 1.10 & $0.17 \%$ & 1.25 \\
\hline Low Analyst & $0.38 \%$ & $2.53 * *$ & $0.28 \%$ & $2.15^{* *}$ & $0.26 \%$ & $2.10^{* *}$ \\
\hline High Analyst & $0.45 \%$ & $2.94 * * *$ & $0.33 \%$ & $2.29 * *$ & $0.28 \%$ & $2.03 * *$ \\
\hline High Dispersion & $0.32 \%$ & $1.97 *$ & $0.17 \%$ & 1.15 & $0.15 \%$ & 1.00 \\
\hline Low Dispersion & $0.58 \%$ & $5.11 * * *$ & $0.49 \%$ & $4.99 * * *$ & $0.46 \%$ & $4.91 * * *$ \\
\hline
\end{tabular}




\section{Table 8. Determinants of Informed Repurchases}

This table presents the results of regressions for each firm having completed a repurchase over the period 1990-2012. Informed is the dependent variable and is an indicator equal to one if the firm causality regression yielded a p-value of $<0.05$ for the six months lagged terms for repurchases. The (REP) or (REP\%) next to Informed indicates if the informed indicator is based on a repurchase indicator or the relative size of the repurchase. REP\% is the percent of the firm to be repurchased in a given month and is equal to the dollar value of the repurchase divided by the market value of the firm in a given month, and used for repurchase size. Rep. Freq. is the number of repurchase programs announced by a given firm during the sample period. Size is the market value of the firm at the time of the repurchase. No. of Analysts is the number of analysts following the firm at the time of the announcement from IBES. Anal. Dispersion is the standard deviation of analyst estimates at the time of the repurchase announcement from IBES. ${ }^{* * *},{ }^{* *}$, and ${ }^{*}$ represent statistical significance at the $1 \%, 5 \%$, and $10 \%$ level, respectively.

\begin{tabular}{|c|c|c|c|c|c|c|}
\hline & (1) & (2) & (3) & (4) & (5) & (6) \\
\hline & $\begin{array}{l}\text { Informed } \\
\text { (REP) }\end{array}$ & $\begin{array}{c}\text { Informed } \\
\text { (REP\%) }\end{array}$ & $\begin{array}{l}\text { Informed } \\
\text { (REP) }\end{array}$ & $\begin{array}{l}\text { Informed } \\
(\mathrm{REP} \%)\end{array}$ & $\begin{array}{l}\text { Informed } \\
\text { (REP) }\end{array}$ & $\begin{array}{c}\text { Informed } \\
\text { (REP\%) }\end{array}$ \\
\hline REP\% & $\begin{array}{c}0.025 \\
(0.061)\end{array}$ & $\begin{array}{l}0.103^{*} \\
(0.062)\end{array}$ & $\begin{array}{c}0.024 \\
(0.061)\end{array}$ & $\begin{array}{c}0.093 \\
(0.062)\end{array}$ & $\begin{array}{c}0.096 \\
(0.081)\end{array}$ & $\begin{array}{c}0.112 \\
(0.080)\end{array}$ \\
\hline Rep. Freq. & & & $\begin{array}{l}-0.002 \\
(0.004)\end{array}$ & $\begin{array}{c}-0.011^{* * * *} \\
(0.004)\end{array}$ & $\begin{array}{l}-0.000 \\
(0.005)\end{array}$ & \\
\hline Size & & & & & $\begin{array}{l}-0.005 \\
(0.004)\end{array}$ & $\begin{array}{c}-0.009 * * * * \\
(0.003)\end{array}$ \\
\hline $\begin{array}{l}\text { No. of } \\
\text { Analysts }\end{array}$ & & & & & $\begin{array}{c}0.089 \\
(0.078)\end{array}$ & $\begin{array}{c}0.126 \\
(0.077)\end{array}$ \\
\hline $\begin{array}{l}\text { Anal. } \\
\text { Dispersion }\end{array}$ & & & & & $\begin{array}{c}0.005 \\
(0.003)\end{array}$ & $\begin{array}{c}0.008 * * * \\
(0.003)\end{array}$ \\
\hline Constant & $\begin{array}{c}0.088 * * * \\
(0.006)\end{array}$ & $\begin{array}{c}0.079 * * * \\
(0.006)\end{array}$ & $\begin{array}{c}0.091 * * * \\
(0.009)\end{array}$ & $\begin{array}{c}0.098 * * * \\
(0.009)\end{array}$ & $\begin{array}{c}0.122 * * * * \\
(0.023)\end{array}$ & $\begin{array}{c}0.148 * * * * \\
(0.022)\end{array}$ \\
\hline Observations & 7,811 & 7,420 & 7,811 & 7,420 & 4,961 & 4,687 \\
\hline $\mathrm{R}$-squared & 0.000 & 0.000 & 0.000 & 0.001 & 0.001 & 0.004 \\
\hline
\end{tabular}

